\title{
Viaje por la Geografía. Una geografía para el mundo. Una geografía para todo el mundo.
}

\author{
Bailly, A., Núñez, A. y Salazar, A. (2018). \\ Viaje por la Geografía. Una geografía para el mundo. \\ Una geografía para todo el mundo. \\ Santiago de Chile: RiL Editores.
}

Reseña elaborada por: Raquel Edith Gurevich*

Viaje por la Geografía invita a un recorrido temático disciplinar, a una ruta por diferentes tópicos geográficos y a la construcción de una mirada conceptual panorámica acerca de diferentes lugares y regiones del mundo. El libro, como objeto material, en sí mismo encarna un viaje que comienza en su propia escritura: editado en Chile, constituye una adaptación, actualización y contextualización a nivel latinoamericano del libro originalmente escrito en Francia, por Antoine Bailly y Renato Scariati (1999), y luego en Portugal con ayuda de José Manuel Simoes (2009). En su versión latinoamericana focaliza en contenidos y casos especialmente situados en Chile, México y Argentina.

A lo largo de sus páginas se presentan contenidos y datos variados, en clave de fragmentos, recortes y casuísticas, que permiten delinear las coordenadas fundamentales del objeto de estudio de la geografía y una selección de sus principales líneas de exploración. Siempre pensando geográficamente, los autores proponen un trabajo de "múltiples luces sobre corrientes de pensamiento de una disciplina que se está permanentemente renovando para responder a las preguntas de nuestras sociedades en el espacio".

La obra no es un manual ni pretende cubrir exhaustivamente los tópicos tratados, sino más bien tematizar y problematizar un conjunto seleccionado de procesos territoriales, así como abrir y plantear conceptualizaciones que dan pie a futuras profundizaciones específicas.
Desde una perspectiva humanista y formando parte de un enfoque cultural, el libro tiene como destinatarios a profesores, estudiantes y público en general, que se encuentren en búsqueda de material sobre un temario seleccionado de geografía que brinde una agenda de problemas y debates significativos del campo. Por su estructura narrativa, permite prácticas de lectura no lineales-ya sea por tema o por capítulo- no respetando una necesaria secuencialidad del orden de las páginas. El texto se expande a través de cruces con material gráfico, fotográfico, paratextos, cartografía, recuadros complementarios de arte y literatura, y a su vez, cada uno de estos componentes pueden leerse de modo independiente o enlazado al texto principal. Así, las posibilidades de significación de los problemas territoriales y ambientales planteados aumentan con la variedad de formatos textuales, aproximaciones conceptuales y narrativas discursivas que el libro propone al lector.

Una introducción, nueve capítulos y una conclusión componen el texto, donde los conceptos de espacio, sujetos, producción, lugar, región y mapa se hacen presentes en un marco de pluralidad, complejidad y singularidad. A lo largo de sus páginas es posible reconstruir la noción de espacio social, permanentemente en transformación e históricamente modelado.

El capítulo uno, La identidad de la geografía, aborda el objeto de estudio dando pistas para la elaboración de un temario posible de docencia e investigación, y tal como los autores proponen, invita a un pensamiento geográfico a través de contenidos como la distancia y proximidad, los medios locales y regionales, la escala y la representación espacial. Por su parte, el sentido de los lugares se desarrolla a partir de las nociones de empatía, 
conocimiento local y el interjuego de escalas. En particular, vale la pena detenerse en la imagen del borde costero de Chile, antes y después del tsunami de 2010, a fin de empirizar las nociones antes planteadas.

Hacer geografía en lo cotidiano es el lema del capítulo número dos, donde se plantean temas que van desde la producción y acceso a bienes y servicios de consumo diario, hasta aquellos ligados a la calidad y modos de vida de las distintas poblaciones. Ejemplos de actividades de alimentación, medicina, cosmética, medios de transporte, agua y saneamiento, entre otros, permiten estudiar grandes procesos geográficos, su complejidad, los actores sociales intervinientes, las tecnologías implicadas y las problemáticas que se suscitan. A modo ejemplo-síntesis, puede subrayarse el enfoque del recuadro "Un desayuno geográfico".

La expansión del espacio es el tema central del tercer capítulo y pone en el centro de la escena la idea de "un espacio que se alarga, un mundo que se encoge". Los conceptos de territorio, flujos y centralidades se utilizan para abordar la reducción del tiempo, la ampliación de rutas, la multiplicación de desplazamientos, la multiplicidad de velocidades y ritmos de los procesos geográficos. Los apartados referentes a la difusión y expansión espacial, al ciclo de las edades y a la apropiación del espacio, aportan a la comprensión y análisis de las múltiples relaciones espacio-tiempo. Por su parte, los mapas de internet y las imágenes de un mundo globalizado apoyan visualmente las conceptualizaciones anteriores.

El capítulo cuatro, Los desequilibrios del territorio, nos habla de un mundo asimétrico, caracterizado por el desarrollo regional desigual y la segregación socio-espacial. A partir de variada información cualitativa y cuantitativa se trabaja la distribución territorial del Índice de Desarrollo Humano (IDH) a escala mundial y el crecimiento inequitativo regional, en especial para el caso chileno. La imagen fotográfica para la segregación socio-espacial en Buenos Aires y las intervenciones urbanas en Santiago de Chile contribuyen a configurar las nociones conceptuales trabajadas.

La noción de Vivir la ciudad organiza el capítulo número cinco. Se presentan las principales características del mundo urbano, intentando responder a la pregunta del porqué vivir en la ciudad. Las urbes como territorios de tensiones, disputas y exclusión, el derecho a la ciudad y los desafíos de la planificación urbana, son algunos de los nudos temáticos que estructuran este capítulo. Se destacan los recuadros "La dimensión ontológica de lo urbano", "Las trampas urbanas de América Latina" y "Un mundo cada vez más urbanizado".

Por su parte, el capítulo seis nos habla sobre las sucesivas construcciones y deconstrucciones que sufren las representaciones gráficas, como objetos culturales e históricos. Se interroga la utilización de la cartografía y de los SIG, y las nociones de representación y de poder se conciben como categorías a desnaturalizar. Los apartados referidos a la lógica social y política de los mapas, el poder territorial, las imágenes y el marketing geográfico invitan a explorar el discurso de los mapas, como portadores de un mensaje y objeto de controversias socio-políticas.
En el séptimo capítulo, titulado Valores y naturalezas del lugar, se aborda un conjunto de conceptos alusivos a "envoltorios indispensables para el funcionamiento en el espacio". Así se formulan las denominadas burbujas espaciales, "mi barrio, mi ciudad, mi país", las heterotopías, como espacios heterogéneos y complejos, que configuran redes de relaciones múltiples, y la noción de finisterra como símbolo de límite o frontera de lo conocido. Estas nociones enriquecen los estudios sobre temas como fronteras, patrimonio, memoria y paisajes culturales, puesto que permiten ampliar los horizontes interpretativos y se nutren de metáforas y figuras ampliatorias para facilitar la compresión de los diferentes lugares del mundo (cafés, playas, bosques, montañas, desiertos, lugares de silencio, lugares de viento).

Desarrollary ordenar el territorio tiene el propósito de aportar al denominado desarrollo sustentable desde la geografía. Se ocupa de plantear sus dimensiones constitutivas, sus dinámicas a largo plazo tanto en regiones como en ciudades, el cambio climático, la Agenda 21, y otros tópicos. Los apartados que trabajan la cohesión regional, el policentrismo urbano y las ciudades sustentables nos hablan de temáticas que afectan las condiciones políticas y económicas de las poblaciones. Se brindan ejemplos de "slow city, ciudades innovadoras, ciudades creativas", subrayando el papel de la planificación y la intervención en los espacios públicos.

En el capítulo nueve se presenta el valor de las biografías, las propias vidas, los espacios vividos, los espacios practicados. Aquí tienen lugar las experiencias, las vivencias, los descubrimientos, los viajes, los rincones, las esquinas, a fin de reconstruir la dimensión simbólica y cultural de los lugares. También se incluyen los espacios virtuales, el ciberespacio y la aldea global, con el objetivo de profundizar la comprensión de artefactos y técnicas de comunicación contemporáneas. Ya, al cierre del texto, Para concluir, un viaje geográfico, se mencionan los cuestionamientos de la disciplina y una reflexión sobre las permanentes transformaciones epistemológicas y metodológicas del campo geográfico. Se comentan las fortalezas y debilidades, y se resalta la vinculación entre el desarrollo conceptual de la geografía y el funcionamiento de la vida cotidiana, a fin de proyectar la vida en clave espacial.

Puede decirse, finalmente, que el libro ofrece conceptos y ejemplos concretos para dar nuevos sentidos a los temas geográficos, no para definirlos de una vez y para siempre, sino para darles vida, enriquecerlos en su diversidad y complejidad, en perspectiva hacia variadas manifestaciones espaciales y sus cambios. Acierta en el ejercicio de una mirada abierta, plural, articuladora del mundo físico, productivo, tecnológico, económico, político y cultural. Y suma la dimensión de la experiencia de los sujetos, habitantes modeladores, constructores y dadores de sentido de cada uno de los lugares del globo, otorgando a la territorialidad la condición de síntesis de la diversidad, de la pluralidad, de lo múltiple. 